\title{
Population trends of common breeding birds in Germany 1990-2018
}

\author{
Johannes Kamp ${ }^{1,2}$ (D) Claudia Frank ${ }^{1,2} \cdot$ Sven Trautmann ${ }^{1} \cdot$ Malte Busch $^{1} \cdot$ Rainer Dröschmeister $^{3} \cdot$ Martin Flade $^{1}$. \\ Bettina Gerlach ${ }^{1}$. Johanna Karthäuser ${ }^{1}$. Friederike Kunz ${ }^{1}$. Alexander Mitschke ${ }^{1}$ - Johannes Schwarz ${ }^{1}$. \\ Christoph Sudfeldt ${ }^{1}$
}

Received: 9 July 2020 / Revised: 14 September 2020 / Accepted: 2 October 2020 / Published online: 22 October 2020

(c) The Author(s) 2020

\begin{abstract}
Biodiversity monitoring is important as it allows to prioritize research into the causes of declines and assessing the efficacy of conservation measures. Regional assessments are valuable, because conservation policies and management are often implemented on national and sub-national level. We analyzed data from the German Common Bird Monitoring for 1990-2018. We derived indices of population size using standard log-linear models, based on point counts and route territory mapping at up to 1200 plots annually. We summarized species trends by ecological trait groups. Among the 93 common breeding birds, farmland birds declined strongly, birds of settlements declined. Forest birds initially declined, but recovered after ca. 2010. Wetland birds increased strongly, albeit the number of species with data was low. Consistent declines were found in ground-nesting birds, granivorous and invertebrate (other than insect)-feeding birds. Trends of insectivorous birds were stable on average, but farmland insectivores declined strongly since the year 2000. Long-distance migrants showed more negative trends compared to short-distance migrants and resident species. Species with narrow habitat niche declined disproportionally. Trends over the entire period were more negative in common species in the dataset (with a German breeding population of $>50 \mathrm{~K}$ and $<1 \mathrm{M}$ pairs). On the opposite, short-term trends were more negative in less common species ( $<50 \mathrm{~K}$ pairs). Cold-adapted species showed largely negative, warm-adapted largely positive trends. Multi-species indicators showed no directional change (i.e., a change from decline to increase or vice versa) conditional on the inclusion or omission of single species, but the magnitude of change was affected in groups with low sample size. This suggests that efforts should be made to develop robust monitoring schemes for rarer species that are not covered by the analyses here. We conclude that conservation policies in Germany should aim at halting the worrying declines in ground-nesting, often insectivorous, farmland birds. The recovery of forest and wetland birds is encouraging, but future trends need to be monitored. Ongoing climate change will affect species directly (via their thermal niche) and indirectly (e.g., through more forest disturbance). Conservation strategies will, therefore, need to consider species adaptation to environmental and climate change, e.g., in better protected area connectivity and management.
\end{abstract}

Keywords Climate change $\cdot$ Land-use change $\cdot$ Forest disturbance $\cdot$ Insect declines $\cdot$ Biodiversity monitoring $\cdot$ Citizen science $\cdot$ Bird migration

Communicated by F. Bairlein.

Johannes Kamp and Claudia Frank are joint first authors.

Electronic supplementary material The online version of this article (https://doi.org/10.1007/s10336-020-01830-4) contains supplementary material, which is available to authorized users.

Johannes Kamp

johannes.kamp@dda-web.de

1 Dachverband Deutscher Avifaunisten (DDA), An den Speichern 2, 48157 Münster, Germany
2 Department of Conservation Biology, University of Göttingen, Bürgerstr. 50, 37073 Göttingen, Germany

3 Bundesamt Für Naturschutz (BfN), Fachgebiet II 1.3 Monitoring, Konstantinstr. 110, 53179 Bonn, Germany 


\section{Zusammenfassung}

\section{Populationstrends häufiger Brutvogelarten in Deutschland 1990 bis 2018}

Monitoringprogramme erlauben Prioritäten bei der Erforschung von Rückgangsursachen zu setzen und die Effektivität von Schutzmaßnahmen zu beurteilen. Regionale Auswertungen von Monitoringdaten bleiben wichtig, denn politische Entscheidungen im Vogelschutz werden oft auf (sub-)nationaler Ebene getroffen, und Managementmaßnahmen implementiert. Wir präsentieren hier eine Analyse der Daten aus dem Monitoring häufiger Brutvogelarten (MhB) des Dachverbands Deutscher Avifaunisten (DDA) für den Zeitraum 1990 bis 2018. Wir haben log-lineare Modelle nach europäischem Standard genutzt, um jährliche Indizes der Populationsgrößen zu berechnen, basierend auf Daten von bis zu 1300 kartierten Probeflächen pro Jahr. Daraus abgeleitete Populationstrends fassen wir für verschiedene funktionale und ökologische Gruppen („Gilden“) zusammen. Unter den betrachteten 93 Arten nahmen die Feldvögel stark, Vögel der Siedlungen deutlich ab. Waldvögel nahmen in den ersten Jahren des Betrachtungszeitraums ab, die Bestände erholten sich aber nach 2010 wieder. Feuchtgebietsarten nahmen stark zu, allerdings enthielt der Datensatz nur acht Arten. Populationsrückgänge wurden für Bodenbrüter, Samenfresser und Wirbellosen- (ohne Insekten)fresser nachgewiesen. Die Bestandstrends von insektenfressenden Vogelarten waren im Mittel stabil, allerdings nehmen insektenfressende Vogelarten des Ackerlandes seit dem Jahr 2000 stark ab. Langstreckenzieher zeigten negativere Trends als Standvögel und Kurzstreckenzieher. Arten mit enger Bindung an bestimmte Habitate nahmen überproportional ab. Über den gesamten Zeitraum betrachtet waren die Trends für die häufigsten Arten im Datensatz (Bestandsgröße in Deutschland 50,000 bis 1 Million Brutpaare) negativer als für mittelhäufige. Im Gegensatz dazu waren kurzfristige (seit 2006) Trends für mittelhäufige Arten negativer als für die häufigen. An kältere Klimabedingungen angepasste Arten nahmen im Mittel ab, an wärmere Bedingungen angepasste Arten zu. Die gemittelten Trends über die Arten einer Gilde (sog. „Multi-species Indicators“) waren relativ robust in Bezug auf einen Richtungswechsel der Trends, wenn einzelne Arten iterativ ausgenommen wurden. Dagegen änderte sich die Stärke des Trends in Gilden mit geringer Stichprobengröße, wenn einzelne Arten ausgetauscht wurden. Dies legt nahe, dass unsere Aussagen noch an Präzision gewinnen würden, wenn weitere, aktuell nicht erfasste Arten in Monitoringprogrammen aufgenommen würden. Wir folgern aus unseren Ergebnissen, dass die Naturschutzpolitik in Deutschland prioritär anstreben sollte, die besorgniserregenden Rückgänge bodenbrütender, oft insektenfressender Feldvogelarten umzukehren. Die Erholung der Bestände der Wald- und Feuchtgebietsarten ist ermutigend, zukünftige Entwicklungen sollten aber überwacht werden. Der Klimawandel wird viele Arten direkt (über ihre Temperaturnische) und indirekt (z.B. durch mehr Störungen im Wald) treffen. Schutzstrategien sollten deshalb die Anpassung von Arten an Umwelt- und Klimawandel berücksichtigen, z.B. durch verbessertes Schutzgebietsmanagement und erhöhte Schutzgebietskonnektivität.

\section{Introduction}

Long-term, structured biodiversity monitoring is important as it allows pinpointing species that decline towards an unfavorable conservation status. Monitoring data can be used to develop hypotheses for drivers and causes of declines in abundance and occupancy (Yoccoz et al. 2001), and to assess the effectiveness of conservation legislation and conservation management (Donald et al. 2007; Pellissier et al. 2019). The earliest biodiversity monitoring schemes were developed for birds, because these are comparatively easy to identify and record and are good indicators of other biodiversity (Mikusiński et al. 2001). Existing volunteer-based schemes for bird monitoring allow assessments of population change for periods spanning up to 50 years (Bystrak 1981; Freeman et al. 2007; Schmeller et al. 2012). In Germany, standardized approaches that laid the foundation for later, structured monitoring schemes were developed in the 1960s (Dornbusch et al. 1968; Oelke 1968).

The value of structured long-term monitoring schemes becomes evident in the current era of rapid environmental change. Outcomes of long-term monitoring schemes have been influencing policymaking and the public opinion, e.g., the recently publicized decline of the avifauna in North America (Rosenberg et al. 2019) or studies on insect declines (Hallmann et al. 2017).

Despite the advances that were made to assess population trends across extensive regions, regional assessments remain important. Country-level data are often more homogenous due to a common sampling protocol (compared to datasets aggregated over several countries). Many conservation measures are implemented on the national or supranational level (e.g., in the European Union, Gregory et al. 2019). Conservation policy, therefore, also needs updated, robust information on the country level, and in federal states such as Germany, even on the sub-country level.

Germany is characterized by a large variety of habitats from sea to high mountains and a pronounced climatic divide between NW Germany (Atlantic climate) and Eastern and Southern Germany (continental climate). Land-use legacies persist, because the country was divided for more than forty years by the iron curtain, and two different political systems shaped land-use and landscapes (Batáry et al. 2017). So far, data on bird population trends from Germany 
were largely only available in aggregated form, e.g., as part of the EU birds directive reporting obligations, (European Environment Agency 2019) or in German-language publications hardly accessible to others than native speakers (Schwarz and Flade 2000; Flade and Schwarz 2004; Gedeon et al. 2014; Gerlach et al. 2019). This includes multi-species indicators, such as the established indicator "species richness and landscape quality" that is based on trends of expertselected bird species and used for assessments of policies to increase sustainable land use in Germany (Dröschmeister and Sukopp 2009).

We here aim to provide an updated synthesis of the grand trends in common bird populations across Germany during the past three decades. We were interested to test how far the following predictions made earlier on European level might be confirmed by an analysis of the very large German data set:

1. habitat preference is a strong driver of population trends, with continuing declines in farmland and especially ground-nesting birds (Heldbjerg et al. 2018; Traba and Morales 2019) and settlement-associated species (Rosin et al. 2020), but stable trends or increases in forest and wetland species (Gregory et al. 2019)

2. populations of insectivorous species have generally declined (Bowler et al. 2019), following dramatic declines in insect abundance and biomass over the past decades (Hallmann et al. 2017; Seibold et al. 2019)

3. long-distance migrants wintering in sub-Saharan Africa continue to decline stronger than short-distance migrants or resident bird species (Sanderson et al. 2006; Vickery et al. 2014)

4. species with narrow habitat and dietary niches decline; whereas those with broader niches increase (Bowler et al. 2019)

5. common species decline stronger than less abundant ones (Inger et al. 2015)

6. bird communities shift towards more warm-adapted species due to accelerating global warming (Stephens et al. 2016).

We discuss potential drivers of population change, and based on this, outline priorities for future research on bird population change in what is one of Europe's largest and most diverse states.

\section{Methods}

\section{Survey design and methods}

The first Common Bird Monitoring scheme in Germany was set up in 1989. The sampling design changed in 2005 when more rigorous standards were introduced. The schemes ran parallel during the period 2005-2010. This overlap allows the calculation of population trends that span the period 1990-2018.

In the "old" monitoring scheme (for details see Schwarz and Flade 2000), observers chose monitoring routes opportunistically (Fig. 1). Point counts along predefined routes were conducted with 10-20 points per route, and a minimum distance of $300 \mathrm{~m}$ between points. Each point was assigned to one of 20 predefined land-cover categories. At each point, all birds were counted for 5 mins (with no settling period), and counts were repeated five times between 15 March and 15 June. A route-specific, annual abundance value was generated by averaging the number of individuals that were recorded over all count rounds. Between 1989 and 2010, 697 plots were surveyed at least in one year, up to 497 per year (Fig. 1). We here include data from 1990 onwards, as the first year of the monitoring schemes is considered a test run.

In 2004, the common bird monitoring in Germany was reorganized. Since then, volunteers map the territories of all breeding birds along routes of approx. $3 \mathrm{~km}$ length four times in the period 10 March-20 June. More than 2600 quadratic sample plots of 100 ha are distributed across Germany (Fig. 1), based on a stratified random sampling approach. The first stratum is Germany's "environmental regions", i.e., spatial units of similar environmental characteristics such as soil, climate and vegetation (Mitschke et al. 2005). The second stratum is land-cover with the classes arable land, rare crops (e.g., grapes and vines), grassland, forest, settlements, and a combined class of rarer land-cover types (heathland, mires, swamps and reeds, wasteland and unvegetated areas, Mitschke et al. 2005). The two strata were chosen to allow separate trend estimation for certain land-cover classes and environmental regions, but also on the level of federal states (that are responsible for nature conservation legislation in Germany). The number of points allocated to each land-cover class varied with total area and land-cover heterogeneity. The number of plots that are successfully surveyed per year, and of which data are fed back to the coordinators, increased since the start of the scheme, but has remained stable at approx. 1200 plots since 2015 . Most plots were surveyed by the same observer for several years. Where the observer changed, and where a large discrepancy in reported bird abundance was apparent comparing the time series before and after the observer change, plots were assigned a new ID and counts were treated as independent time series, to avoid strong observer effects on population trends (both in the old and the new scheme). This concerns $11 \%$ of all plots ever surveyed. Only plots that were surveyed in at least two years by the same observer were included in the analysis, and the first year of each plot- and observer-specific time series was discarded to avoid effects of observer learning. 

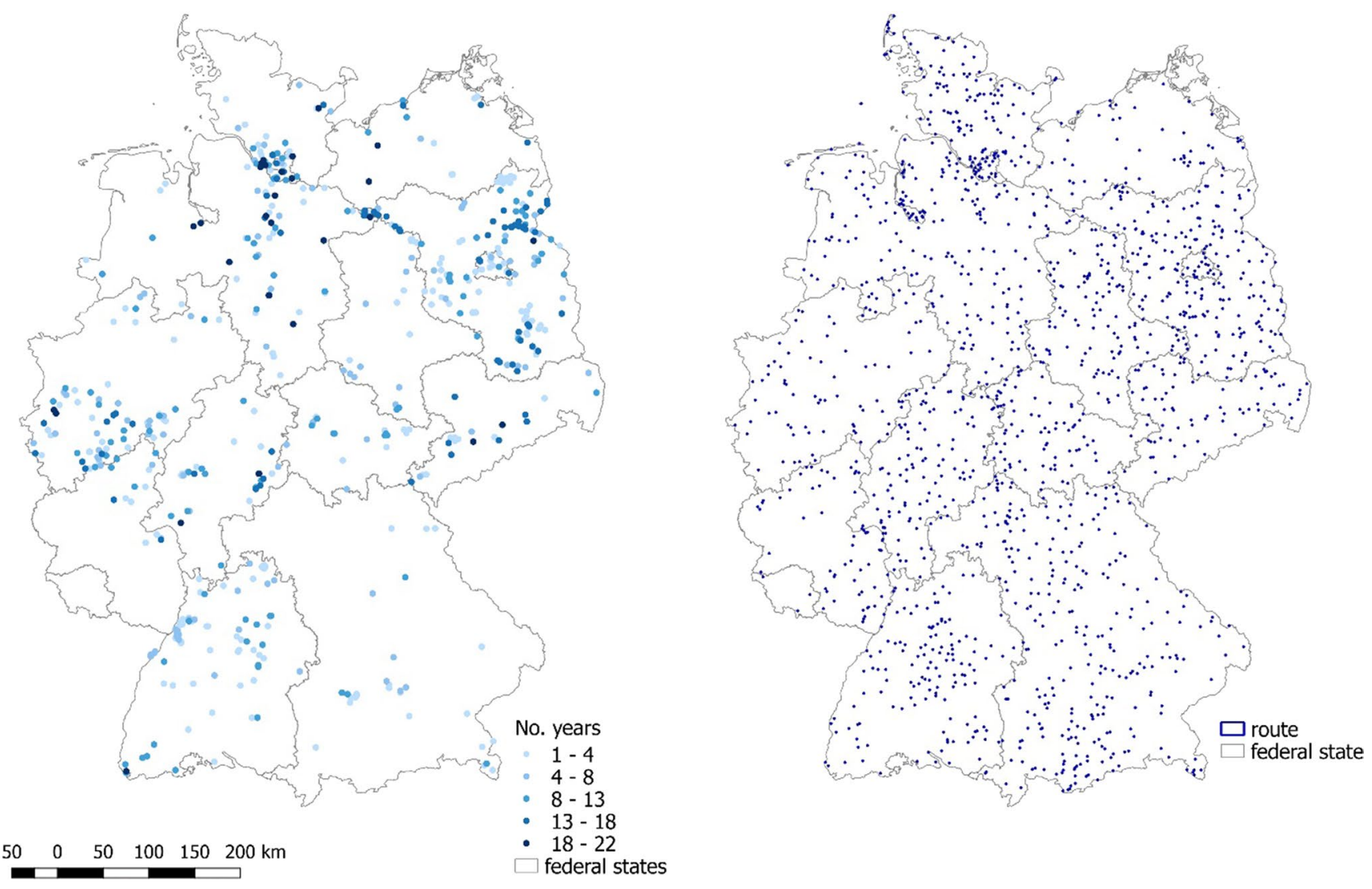

Fig. 1 Location of monitoring plots surveyed between 1989 and 2010 (left; color intensity indicates the number of years with data) and 20052018 (right)

\section{Trend estimation}

We considered 93 species that constitute the standard reporting set of the monitoring scheme. These are species that were recorded on at least 30 plots annually across Germany, and for which a power analysis (repeated-measures ANOVA) indicated that sample size is large enough to allow the calculation of reliable trends for the period 1990-2018. Their estimated national population sizes range from 11,500 (Eurasian Wryneck, Jynx torquilla) to 8.6 million breeding pairs (Eurasian Blackbird, Turdus merula).

Trends with their associated standard errors were estimated in TRIM (TRends and Indices for Monitoring data, Pannekoek and Van Strien 2001), the standard tool applied in most schemes of the Pan-European Common Bird Monitoring Framework (Gregory et al. 2019). In TRIM, time-series of counts are analyzed in a Poisson regression framework (log-linear regression). Model parameters are estimated with maximum likelihood methods in a Generalized Estimation Equations (GEE) approach, allowing to correct for overdispersion and serial correlation of counts. Missing counts from sites not covered in single years are estimated ("imputed") from changes at all other sites.

Because recording methods, sampling design and effort were not comparable between the "old" (1990-2010) and the "new" (since 2005) monitoring scheme (Fig. 1), annual indices were first calculated separately for both schemes. The index was set to 1 (with standard error 0) in year 2006 in both schemes. Values for the period of overlap (2005-2010) were then generated in the following way: For each year of the overlap period, and for both schemes separately, the index for each species was simulated 10,000 times by drawing from a normal distribution $N(\mu, \sigma)$ with $\mu=$ the value of the TRIM index and $\sigma=$ the standard error of the index. The 10,000 values were then averaged over the two schemes, and an overall mean and the associated standard error were used as annual indices and uncertainty estimates for each year of the period of overlap (2005-2010). For each species, an overall trend spanning the entire period of interest from 1990 to 2018 was obtained by regressing the annual abundance index against year in a linear regression. 


\section{Species traits}

We were interested to explore potential differences in trends between groups of species sharing ecological characteristics (traits) that resulted in a common degree of sensitivity to threats, or are related to shared population drivers outside the breeding range. Species trait data were sourced from an extensive, unpublished database (Wahl et al. 2014, unpublished, overview in the supporting online material, Table S1).

Finer categories of species' main breeding and foraging habitat were combined into the categories wetlands, open habitat, farmland, forests and settlements. Open habitat contained non-farmland such as heathland and mire. Forest contained deciduous, coniferous and mixed stands. Some species used different habitats for breeding and foraging. Common Buzzard, Common Kestrel, Common Starling, Fieldfare, Red Kite and Turtle Dove were classified as farmland birds since drivers of population trends were considered to be stronger in their foraging compared to their breeding habitat (Busch et al. 2020). When species used routinely more than one habitat (usually generalist species), they were assigned to the category "several". According to their nest site preferences, species were grouped into nest site categories comprising trees, shrubs, buildings, reeds and ground-level breeders. Species breeding close to wetland fringes were assigned to the category reeds. Ground-level breeders were either breeding directly on the ground or in the herb layer close to the ground. If there was no clear preference in nest site location, species were assigned to the category "indifferent" and not considered for analysis. The nest parasite Common Cuckoo was not assigned to any of these categories.

Dietary niche comprised the classes omnivorous, carnivorous, granivorous, herbivorous and insectivorous species (including spiders). Insectivores were further split into insectivorous forest dwellers and insectivorous farmland birds. Insectivores not belonging to either of these two categories were grouped as "insectivorous other". The category "invertebrates" was used for those species that preferentially feed on molluscs, earthworms and other (non-insect) invertebrates. Migration strategies were assigned using species-specific migration distances based on ringing recoveries (Berthold 2008; Bairlein et al. 2014). Species were characterized as either resident (nonmigratory) species, short-distance (distance breeding to wintering range $<3000 \mathrm{~km}$ based on ringing recoveries) or long-distance migrants (distance $>3000 \mathrm{~km}$ ). Migrant species were further differentiated by their main wintering grounds. Long-distance migrants were split into species wintering in the Sahel-Sudan and species wintering in Sub-Sahel from Guinea to Congo and South-East Africa.
Long-distance migrants without clearly preferred wintering grounds were assigned the category "Afrotropics (indifferent)". We distinguished short-distance migrants wintering in the Atlantic region from those wintering in the Western Mediterranean. Those that were indifferent to these biogeographic regions were assigned the category "Western Westpalearctic".

We categorized species by habitat and dietary specialization based on Storchová and Hořák (2018). We summarized the number of habitats and diet types used during the breeding period per species. Species using more than one habitat type or falling into more than two diet categories were assigned to the category "broad" since they were considered to be habitat or diet generalists. Species using one habitat type and those using one or two diet types were considered diet specialists and assigned to the category "narrow".

We used estimates of the national population size for all German breeding birds for the period 2011-2016 (Gerlach et al. 2019) to assign species to classes of "commonness". Species with a population size of less than 50,000 breeding pairs/territories were considered "less common", with a population size between 50,000 and one million were considered "common", and those with a population size of over one million were considered "abundant". To characterize species by their temperature preferences, we used the European species temperature index (STI) (Devictor et al. 2008). The lower quartile of STIs of all species included in our analysis (values below $11.6^{\circ} \mathrm{C}$ ) was considered to represent coldadapted species whereas the upper quartile of STIs (values above $12.9^{\circ} \mathrm{C}$ ) was considered to represent warm-adapted species. STIs in-between were considered species with an intermediate temperature preference. We only considered trait categories that were assigned to at least eight species for analysis.

\section{Multi-species indicators}

Annual indices of species-specific abundance were used as input for multi-species indicators (henceforth MSI). We used Monte Carlo simulations following Soldaat et al. (2017) to derive trajectories and confidence intervals of multi-species indicators based on yearly species indices and their standard errors. Each available yearly index for each species was simulated 1000 times by drawing from a normal distribution $N$ $(\mu, \sigma)$ with $\mu=$ the natural logarithm of the index and $\sigma=$ the standard error of the index on the log scale. A geometric mean, standard error and confidence limits from the 1000 simulated MSIs were calculated for each year and back-transformed to an index scale. Species with a mean coefficient of variation $>10$ were excluded from analysis, a maximum year-to-year index ratio $>10$ was truncated to 10 in case of an increase and to 0.1 in case of decrease to minimize the effect that species with 
strongly fluctuating populations have on the MSI. We also truncated indices $<1$ to 1 and set their standard errors to 0 to exclude large variation caused by high standard errors of species with smaller populations. However, this was rarely the case due to the large sample size of monitoring plots and the relative commonness of most species. The year 1990 was set as base year with index value 100 and standard error 0 . All other years were expressed as percent change from the base year. We tested for the significance of the multi-species trends over two time periods, a long-term trend 1990-2018, and a short-term trend 2006-2018. As visual inspection of mean species trends suggested directional changes in trend trajectories around the year 2010, we tested for the statistical significance of this year as a changepoint following Soldaat et al. (2017). Overall trends for the two time periods are reported in the results (below), trends expressed as mean $\%$ change per year for comparison of the two time periods are reported in Table S3. To test for the sensitivity of the MSI to the inclusion of trends of changing species assemblages, we simulated multi-species indicators leaving one species out at a time.

\section{Results}

\section{Habitat and nest site preference}

Over the period 1990-2018, farmland birds exhibited a strong decline; birds of settlements a considerable decline. Forest birds and bird species using several habitat types showed stable population trends. Wetland species showed a strong increase (Fig. 2, Table S1). The MSI suggested stable farmland bird populations until 2000 and a rapid decline afterwards, and recovery in forest bird populations after ca. 2010, with a significant changepoint in this year. These trends were largely mirrored in nest-site preferences, with positive mean trends for tree, shrub and building breeders but negative trends in ground-breeders (Fig. 3; Table 1). Excluding the naturalized Feral Pigeon (Columba livia $f$. domestica) resulted in a more negative trend of the birds of settlements functional group (MSI analysis, long-term trend: $-22.7 \% \pm 2.6 \mathrm{SE}$ vs. $-16.3 \% \pm 3.3 \mathrm{SE}$ ) and a more negative trend of the building-breeders, mirroring the overall positive trend of the Pigeon (MSI analysis, long-term trend: $-13.4 \% \pm 3.4$ SE vs. $-5.5 \% \pm 4.3$ SE, Fig. S6; Table S2). Excluding Common Pheasant, whose populations are driven by shooting and supplements, did not change any of the multi-species trends in any group (Fig. S6; Table S2).

\section{Diet}

Over the period 1990-2018, insectivorous species showed on average stable trends. Granivorous birds and birds feeding on invertebrates other than insects (e.g., earthworms) showed a mean negative trend (Fig. 2, Table S1), with the MSI suggesting declines until ca. 2010, but a stabilization or slight recovery afterwards. The 2010 changepoint was significant for granivorous birds and those feeding on invertebrates (Table 1). Farmland insectivores increased until 2000 and then declined, but uncertainty was high. Insectivorous forest birds significantly increased since 2006 (Fig. 3; Table 1).

\section{Migration strategy and wintering region}

Over the period 1990-2018, long-distance migrants decreased, while populations of short-distance migrants were stable and populations of resident species increased. Migrants wintering south of the Sahel zone declined strongest, and across nearly all species (Fig. 2). Long-distance migrants wintering in the Sahel-Sudan region showed a mean positive trend but large variation in species-specific trends (Fig. S1; Table S1). The MSI suggested a stronger increase of species wintering in Germany from 2006 onwards. Migrants wintering in the western Mediterranean decreased until around ca. 2010, but recovered afterwards (significant changepoint in 2010, Fig. 3; Table 1).

\section{Habitat and dietary specialization (niche breadth)}

Species with a narrow habitat and dietary niche significantly declined over the period 1990-2018. Habitat generalist species with a broad habitat niche showed rather stable population trends with a short-term increase from around 2006 on (Table 1; Figs. 4, 5). The 2010 changepoint was significant for this group (Table 1). In habitat specialists, a decrease was mainly driven by a steeper short-term trend since 2006. Diet generalists feeding on more than two diet types increased, while diet specialists feeding on one or two diet types decreased over the period 1990-2018 (Table 1; Fig. 5).

\section{Population size}

Abundant species showed on average stable, common species negative and less common mainly stable trends over the period 1990-2018 (Fig. 4). Trends in less common species varied strongly; whereas variation in trend strength and direction was lower in common and abundant species (Fig. S2). Less common species increased until 2006 but then decreased. Abundant and common species decreased until around 2010, followed by an increase or stabilization 
Fig. 2 Summaries of speciesspecific linear trend estimates (annual mean change, additive TRIM values) 1990-2018 for the traits habitat, nest site, diet, migration strategy and wintering region. Trends for insectivores are presented separately for farmland, forest and all other species. In this and the following figures, box limits mark the interquartile (IQR) range and are divided by the median. Whiskers extend to a maximum of 1.5 times the IQR beyond the box. Dots are data points beyond 1.5 times the interquartile range. Categories of functional groups are ordered by the median
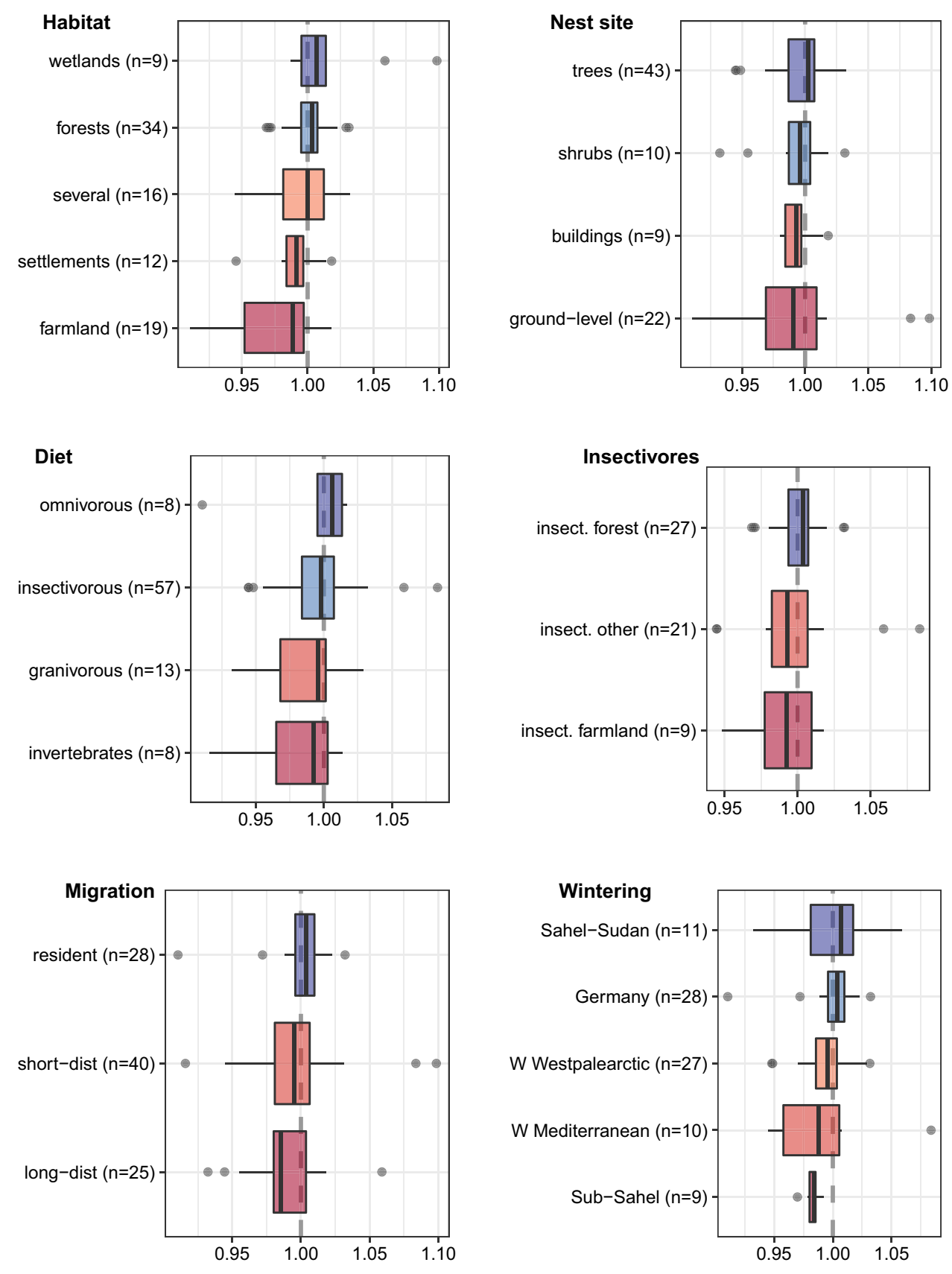

(Fig. 5). In both groups, the 2010 changepoints were significant.

\section{Temperature preference}

Species preferring low temperatures declined; species with preference for high temperatures mainly increased over the period 1990-2018. Species in between also showed rather negative population trends (Fig. 5;
Table 1). For all groups, population trends stabilized recently (Fig. 5; Table 1).

\section{MSI sensitivity}

The sensitivity of the MSI to single species being included or omitted was dependent on the number of species per trait category, and variation in trend strength among species in this category. Categories containing a larger number of 
Fig. 3 Multi-species indicators 1990-2018 for the traits habitat, nest site, diet, migration strategy and wintering region. Trends for insectivores are presented separately for farmland, forest and all other species. In this and the following plot, dots are annual simulated indices, error bars are standard errors, and the line is a nonparametric scatterplot smoother (loess) with $95 \%$ confidence bands (to ease visual interpretation of trend trajectories)

\section{Habitat}

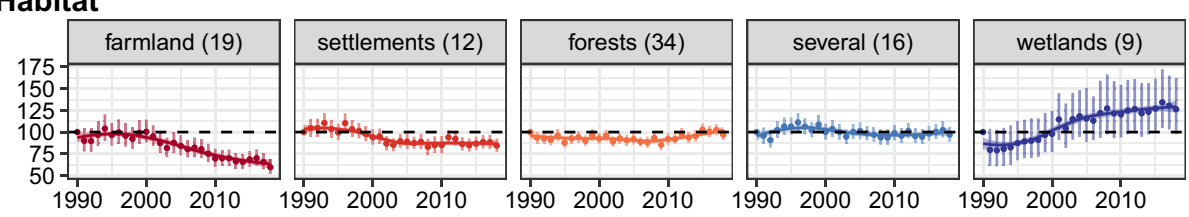

Nest site
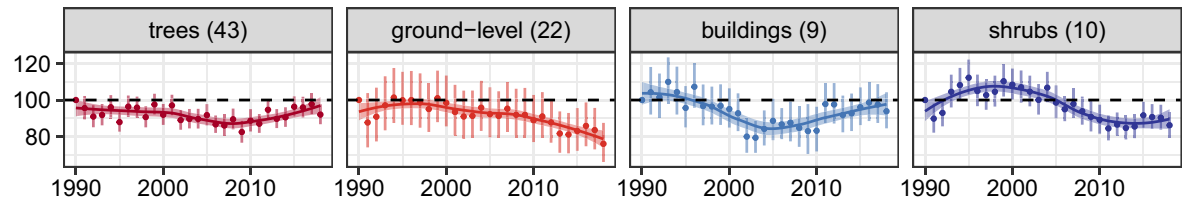

음

Diet

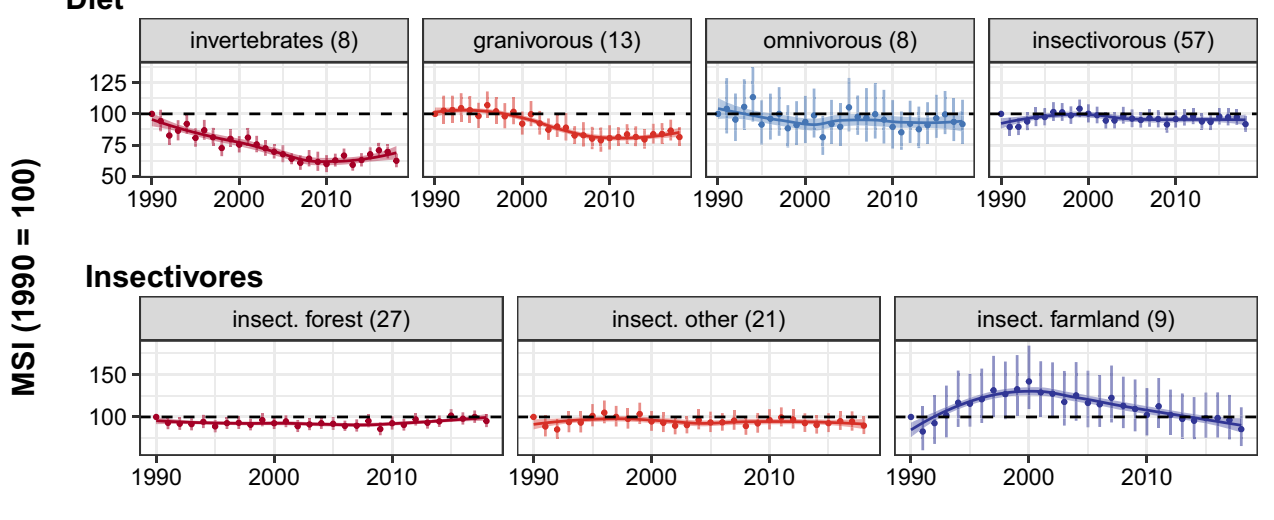

Migration
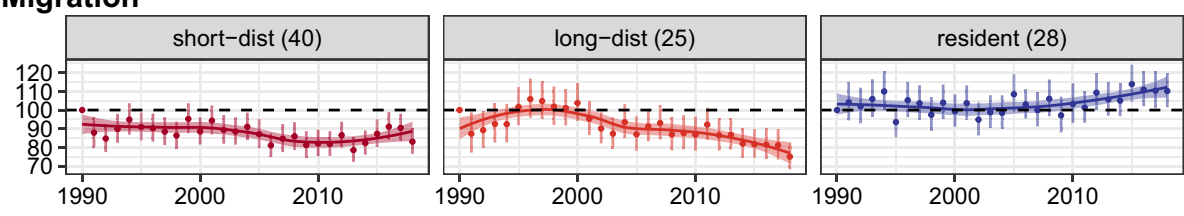

Winter
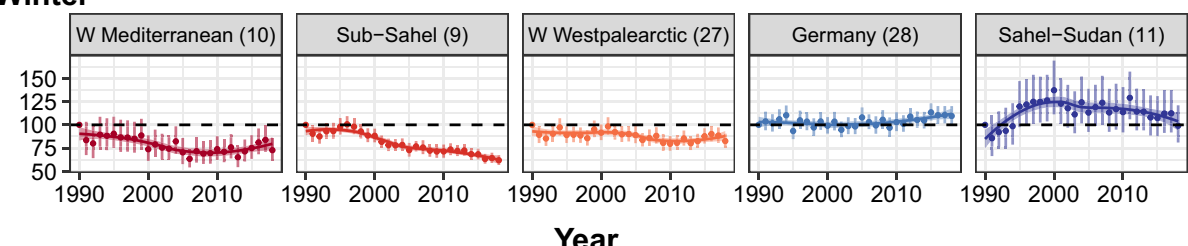

Year species were rather robust to the omission of any species (Figs. S3, S4). An exception was the MSI of species with a narrow habitat breadth and omnivorous species, where the omission of a single species did affect not only trend magnitude, but also direction (Figs. S3, S4).

\section{Discussion}

We summarized the grand trends in common bird populations across Germany for the period 1990-2018. We found several of our predictions confirmed: (i) farmland (especially ground-nesting) birds continue to decline, whereas forest and wetland birds have recently been increasing in numbers; (ii) long-distance migrants continue to decline stronger than resident or short-distance migrants; (iii) habitat generalists show stable trends whereas specialists decrease in numbers, and (iv) warmadapted species show more positive population trends than cold-adapted ones. We could not confirm a general decline in insectivorous birds. The relation between national species abundance and trend was somewhat ambiguous and varied over different time periods. 
Table 1 Trend (\% change) for the period 1990-2018 with associated standard errors and p-values for all traits considered in the MSI analyses. “\% change 2006" gives the short-term trend (\% change) for the past 12 years 2006-2018

\begin{tabular}{|c|c|c|c|c|c|c|c|c|}
\hline Functional group & Trait class $(n)$ & $\%$ Change & SE & $p$ & \% Change 2006 & SE & $p$ & $p$ (changepoint) \\
\hline Habitat & Farmland (19) & -32.4 & 3.854 & $p<0.01$ & -17.1 & 3.994 & $p<0.01$ & n.s \\
\hline Habitat & Forests (34) & 7.1 & 3.014 & $p<0.05$ & 13.2 & 2.937 & $p<0.01$ & $p<0.01$ \\
\hline Habitat & Settlements (12) & -16.3 & 3.28 & $p<0.01$ & -0.3 & 3.47 & n.s & n.s \\
\hline Habitat & Several (16) & 4.9 & 4.056 & n.s & 3.3 & 3.947 & n.s & n.s \\
\hline Habitat & Wetlands (9) & 51 & 15.81 & $p<0.01$ & 10.8 & 15.286 & n.s & n.s \\
\hline Nest site & Buildings (9) & -5.5 & 4.36 & n.s & 11.9 & 4.403 & $p<0.01$ & $p<0.01$ \\
\hline Nest site & Ground-level (22) & -15.6 & 5.259 & $p<0.01$ & -14.7 & 5.134 & $p<0.01$ & n.s \\
\hline Nest site & Shrubs (10) & -4.6 & 3.219 & n.s & -5.5 & 3.247 & n.s & n.s \\
\hline Nest site & Trees (43) & 1.6 & 2.616 & n.s & 10.2 & 2.448 & $p<0.01$ & $p<0.01$ \\
\hline Diet & Granivorous (13) & -15.9 & 3.455 & $p<0.01$ & 2.3 & 3.38 & $\mathrm{n} . \mathrm{s}$ & $p<0.01$ \\
\hline Diet & Insectivorous (57) & 3.2 & 3.061 & n.s & -0.3 & 2.971 & n.s & n.s \\
\hline Diet & Invertebrates (8) & -27.8 & 2.687 & $p<0.01$ & 5.4 & 2.701 & $p<0.05$ & $p<0.01$ \\
\hline Diet & Omnivorous (8) & -9.6 & 7.07 & n.s & -0.8 & 7.381 & n.s & n.s \\
\hline Insectivores & Insect. farmland (9) & 4.9 & 11.946 & n.s & -28.7 & 12.605 & $p<0.05$ & n.s \\
\hline Insectivores & Insect. forest (27) & 4.3 & 3.389 & n.s & 9.4 & 3.315 & $p<0.01$ & n.s \\
\hline Insectivores & Insect. other (21) & 0.6 & 5.139 & n.s & -2.4 & 4.966 & n.s & n.s \\
\hline Migration & Long-distance (25) & -14.4 & 3.64 & $p<0.01$ & -13.9 & 3.61 & $p<0.01$ & $p<0.05$ \\
\hline Migration & Resident (28) & 9 & 3.875 & $p<0.05$ & 10.3 & 3.82 & $p<0.01$ & n.s \\
\hline Migration & Short-distance (40) & -3.8 & 3.286 & n.s & 4.8 & 3.25 & n.s & $p<0.05$ \\
\hline Wintering & Germany (28) & 8.8 & 4.212 & $p<0.05$ & 10.3 & 3.915 & $p<0.01$ & n.s \\
\hline Wintering & Sahel-Sudan (11) & 20.8 & 10.498 & $p<0.05$ & -16.7 & 10.514 & n.s & $p<0.05$ \\
\hline Wintering & Sub-Sahel (9) & -32.7 & 2.439 & $p<0.01$ & -12.6 & 2.529 & $p<0.01$ & n.s \\
\hline Wintering & W Mediterranean (10) & -11.1 & 6.402 & n.s & 10.3 & 5.919 & n.s & $p<0.05$ \\
\hline Wintering & W Westpalearctic (27) & -5.2 & 3.626 & n.s & 3.4 & 3.625 & n.s & $p<0.05$ \\
\hline Diet breadth & Broad (20) & 16.7 & 6.509 & $p<0.05$ & 3.9 & 6.513 & n.s & n.s \\
\hline Diet breadth & Narrow (72) & -9.1 & 2.04 & $p<0.01$ & 0.1 & 2.061 & n.s & n.s \\
\hline Habitat breadth & Broad (75) & 1.5 & 1.915 & n.s & 6.5 & 1.873 & $p<0.01$ & $p<0.01$ \\
\hline Habitat breadth & Narrow (17) & -24.6 & 6.114 & $p<0.01$ & -20.7 & 6.521 & $p<0.01$ & n.s \\
\hline Population size & Abundant (21) & 3.8 & 1.589 & $p<0.05$ & 8.9 & 1.536 & $p<0.01$ & $p<0.01$ \\
\hline Population size & Common (48) & -12.1 & 1.648 & $p<0.01$ & 1.2 & 1.663 & n.s & $p<0.01$ \\
\hline Population size & Less common (23) & 6.5 & 8.078 & n.s & -9 & 8.163 & n.s & n.s \\
\hline Temperature preference & Interquartile (45) & -10.2 & 2.059 & $p<0.01$ & -0.2 & 2.078 & n.s & n.s \\
\hline Temperature preference & Lower quartile (23) & -13.4 & 3.723 & $p<0.01$ & 0.7 & 3.713 & n.s & n.s \\
\hline Temperature preference & Upper quartile (24) & 20.2 & 7.195 & $p<0.01$ & 3.4 & 6.806 & n.s & n.s \\
\hline
\end{tabular}

$p$ (changepoint) is the $p$ value that denotes if the 2010 changepoint is significant or not significant (n.s.)

\section{Trends across land-cover types}

Farmland birds have long been in the focus of European conservationists as declines reach back to the 1950s (Newton 2004). In Germany, farmland birds declined between 1970 and 1990 (Nicolai 1993; Donald et al. 2001). We here show that there was a temporary period of relative population stability in the early 1990 s, before heavy declines set in anew. This likely resulted from changes in the agricultural system of East Germany: during the transition from a state-controlled to a market-oriented economy, many agricultural enterprises were less productive or were shut-down
(Swinnen and Vranken 2010; Swinnen et al. 2018). This resulted in large crop- and grassland areas that were left fallow or were abandoned for extended periods, especially on poorer soils (George 2004; Görn et al. 2015). Abandonment and recultivation patterns have been driving EU-wide trends of farmland birds in several former eastern bloc countries (Reif et al. 2008; Sanderson et al. 2013; Zakkak et al. 2015). A recultivation of abandoned land, accompanied by an increase in management intensity, started with the mid1990s. Regional differences with consistent declines since 1990 in Western Europe, but recovery during the 1990s in Eastern Germany, have been described for farmland bird 
Fig. 4 Summaries of speciesspecific linear trend estimates (annual mean change, additive TRIM values) 1990-2018 for the traits diet breadth, habitat breadth, population size in Germany and species temperature preference
Fig. 5 Multi-species indicators 1990-2018 for the traits diet breadth, habitat breadth, population size in Germany and species temperature preference
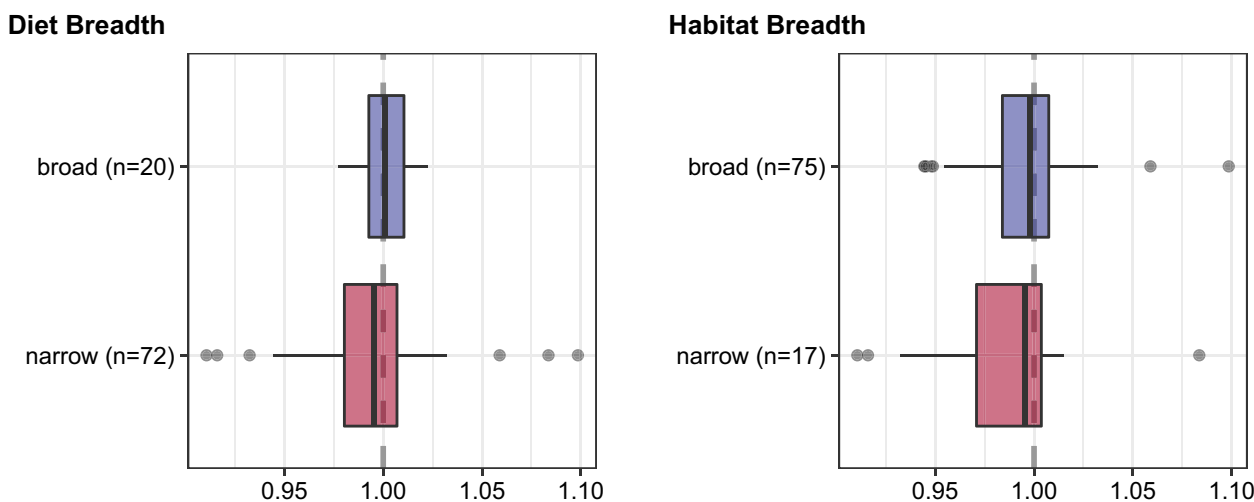

\section{Population size}

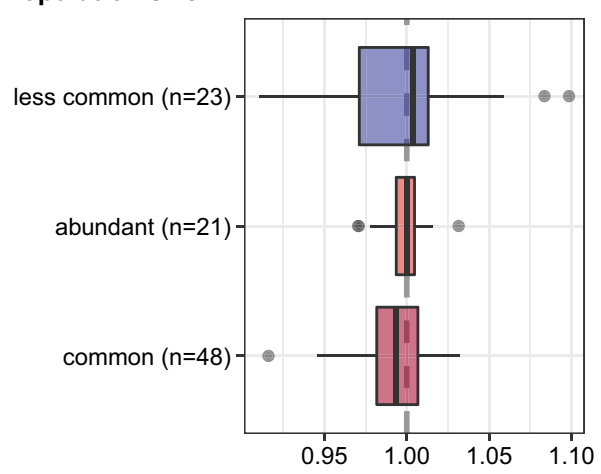

Estimate (1990-2018)

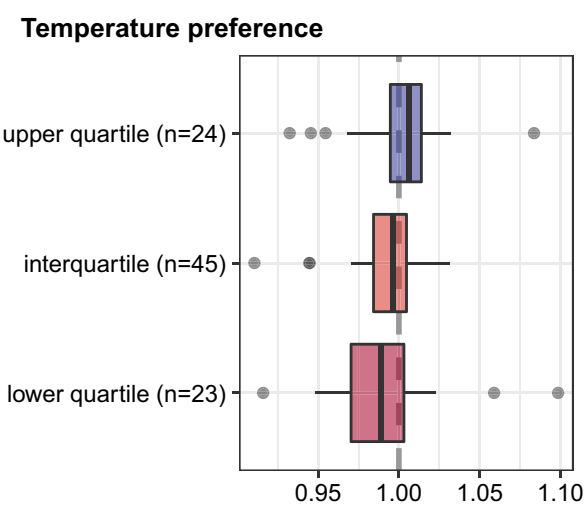

Habitat Breadth

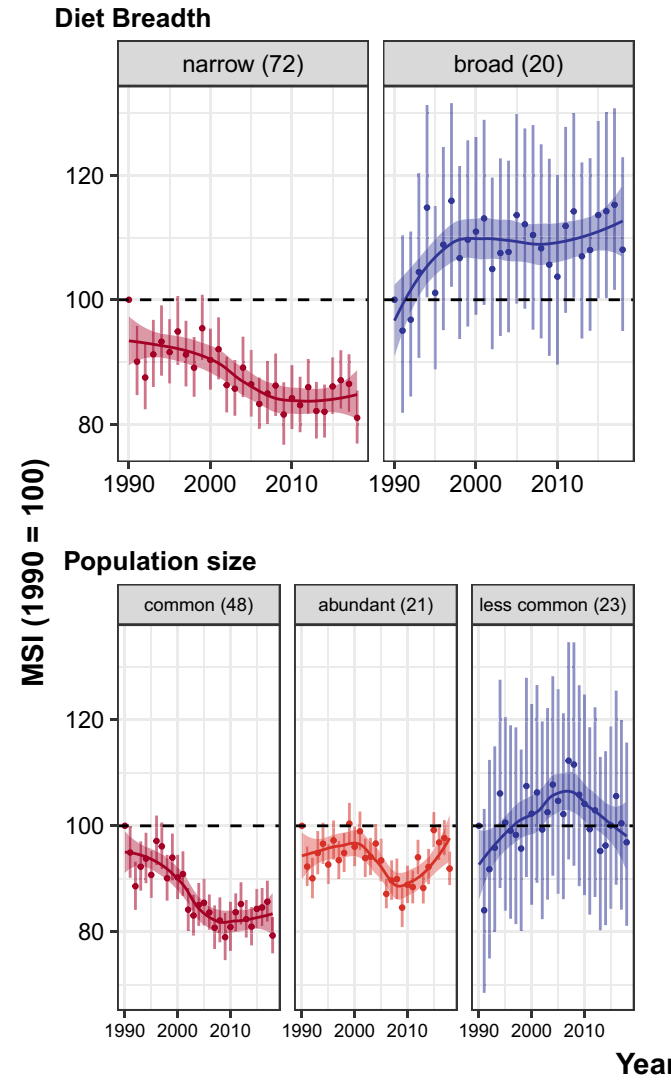

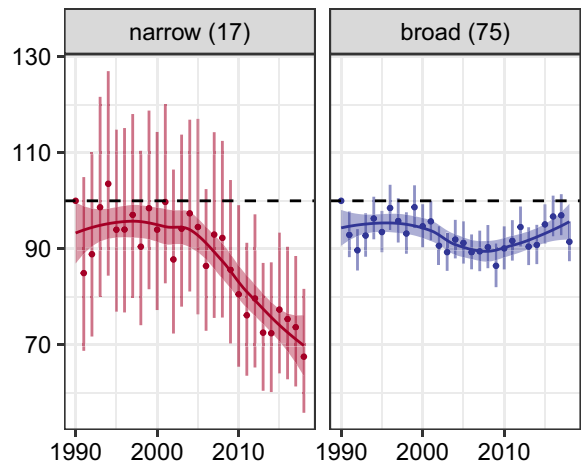

Temperature preference

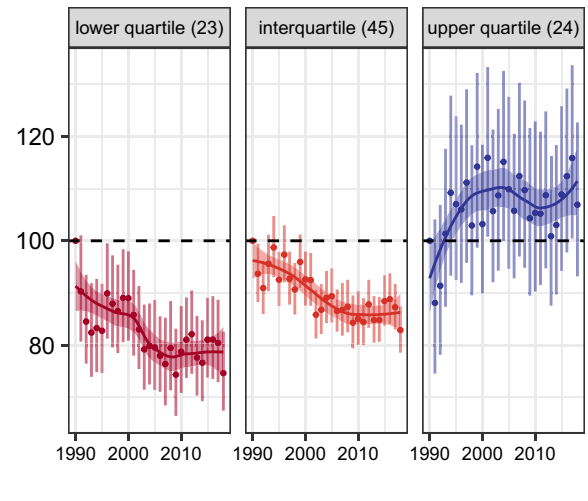


species such as Common Starling, Corn Bunting, Yellowhammer; but they are not visible in other farmland species. This suggests the east-west divide was not the only driving force after the year 2000 (Busch et al. 2020).

After the year 2000, common farmland birds declined in Germany, and this trend is still accelerating in many species such as Grey Partridge and Northern Lapwing ( $>80 \%$ decline over the entire period). The drivers of these recent trends can be summarized under the heading of an ever-increasing land-use intensity (Jerrentrup et al. 2017; Deutsche Ornithologen-Gesellschaft and Fachgruppe Agrarvögel 2019; Busch et al. 2020). For farmland, these are, among others, the loss of fallows and set-aside; simplification and homogenization of the agricultural landscape through an increase in field size; loss of spatial and temporal crop diversity (e.g., increase in maize, loss of summer cereals, simpler crop-rotation cycles); and possibly an increase in highly efficient pesticides. Apart from an ongoing conversion of grassland to cropland, grassland management is characterized by intensification through increased fertilizer (including organic manure) inputs, a resulting increase in cuts per year and denser swards, and frequent reseeding with high-yielding grass crops.

Common forest birds showed a stable to slightly decreasing trend between 1990 and ca. 2010, but have been increasing since. Forest area and average stand age have increased steadily across Europe since 1850, and growing stock volume more than tripled from ca. 4 to ca. 14 billion $\mathrm{m}^{3}$ between 1948 and 1995 (Schelhaas et al. 2003). In Germany, this trend continues, with a $7 \%$ increase in wood volume between 2002 and 2012 and an increase in dead wood by $18 \%$, to a proportion of $6 \%$ of the live standing wood (Federal Ministry of Food and Agriculture 2015). This might explain the long-term positive trends in a number of oldgrowth species, e.g., Stock Dove or Middle Spotted Woodpecker. Climate change effects (e.g., a higher winter food availability for resident species through an increased frequency of tree masts) might drive population increases in forest birds (Grendelmeier et al. 2019). Future trends in forest birds will also depend on forest disturbance: Crown mortality due to drought and extreme events such as windthrow and bark beetle outbreaks have been increasing over the past 30 years and are expected to further increase due to climate change (Senf et al. 2018, 2020; Senf and Seidl 2020). Canopy opening might explain the flattening of negative trends in birds of early successional forest stages such as Tree Pipit, Willow Warbler and Wryneck (Kamp et al. 2020, Fig. S5) that had likely suffered from the darkening of the forests through increased wood volume and canopy closure since the 1950s.

The considerable decline of common birds of settlements after a period of stability in the early 1990s might partly be explained by changes in the rural landscapes of Eastern
Germany (Schwarz and Flade 2000). The abandonment of farmsteads in the post-Socialist period, and the state of the housing infrastructure in Eastern Germany in the 1990s (where many buildings had not been refurbished since preWWII-times, unlike in Western Germany) provided niches for species nesting in buildings that were lost when modernization set in (Schwarz and Flade 2000). Similar developments were seen in other former Eastern Bloc countries, such as Poland (Šálek et al. 2018; Rosin et al. 2020). In recent years, the decline of settlement species has leveled off, with evidence for a stable trend since ca. 2003 (Fig. 3, Fig. S6). This could be linked to more green spaces due to increased shrub and tree age in urban parks and gardens or increased bird feeding activities (Robb et al. 2008). It could also have resulted from a stricter Germany-wide implementation of EU law that makes compensation mandatory for nest sites and niches that had been destroyed during building refurbishment since ca. 2006.

Common wetland species increased on average, although this conclusion is based on only nine species (of which none is characteristic of flowing waters), comprising two species with strong increases (Greylag Goose and Sedge Warbler), two declining species (Great Crested Grebe and Reed Bunting) and five species with fluctuating or stable populations over the examined period (Mallard, Little Grebe, Common Moorhen, Common Coot and Eurasian Reed Warbler). The diversity of ecological niches these species occupy and their diverging traits make it difficult to explain a guild-wide trend, and species-specific studies are required. Furthermore, the number of monitoring plots with data was rather small in the early years of the monitoring scheme, and locational bias high, e.g., for Little Grebe, suggesting that waterbird trends need to be treated with care, and more targeted monitoring schemes for breeding waterbirds need to be developed.

Patterns in nest site preferences of common birds largely mirrored the trends of the habitat guilds discussed above, with ongoing declines of ground-nesting (largely farmland) birds and recent increase in tree-nesters (mostly woodland birds) and recovery in birds nesting at buildings in settlements.

\section{Trends by foraging niche}

We could not confirm an anticipated general decline in insectivorous birds (Bowler et al. 2019). Common insectivorous farmland birds started declining again after the year 2000 , later than the onset of a dramatic loss of flying insect biomass in open habitats around the year 1990 (Hallmann et al. 2017). Forest insectivores exhibited on average stable trends, with a recent slight recovery in numbers, and insectivores of the remaining habitats including settlements showed a stable trend over the entire period. Invertebrate 
feeders instead showed the strongest declines on average. It is well established that a shortage and availability of invertebrates can lead to population declines, via mechanisms such as low chick survival, and especially so in farmland birds (Newton 2004; Schekkerman 2008). Yet, the implications of recent, pronounced declines in insect biomass and abundance (Hallmann et al. 2017; Seibold et al. 2019) for bird survival and population trends are still poorly understood. We also detected an ongoing decline in common granivorous birds (seed-eaters), with perhaps a very recent stabilization. This guild of species has long known to be declining due to herbicide use and the disappearance of spring-sown cereals at the cost of winter-sown grains (Newton 2004). It has to be seen if the populations of granivorous species will stabilize, or if declines resume with the exposure of farmland birds to high levels of ever more efficient pesticides (Lennon et al. 2020) that can have sub-lethal effects such as impairing migratory ability in granivorous species (Eng et al. 2017).

The detected strong declines in common long-distance migrants, especially those wintering in sub-Sahelian Africa are well-known across Europe (Sanderson et al. 2006). There is likely no unifying driver acting on the wintering grounds (Vickery and Adams 2020), especially as patterns of vegetation change and climate-change impacts are spatially highly variable (Beresford et al. 2019). Climate and weather fluctuations have driven population trends in the past (Vickery et al. 2014), alongside increasing human land-use intensity. More recently, evidence is mounting that habitat change on the wintering grounds has probably less impact than on the breeding grounds in this flyway (Cresswell et al. 2019; Busch et al. 2020).

\section{Trends in relation to national population size}

Our analyses regarding the "commonness" of species are little precise, because the dataset used allows the calculation of trends only for species with a German population of more than 10.000 breeding pairs. Truly "rare" species that are in the focus of conservation management and protected area designation are, thus, not covered here. There is good evidence from regional time series and expert estimates that especially rare, conservation-dependent species such as large raptors, storks, herons and waterbirds have recently recovered from their all-time population lows in the early twentieth century (Gerlach et al. 2019). In the analysis presented here, we do find a clear signal of declines in common species between 1990 and ca. 2009 that matches trends across Europe (Inger et al. 2015). This is worrying because common species are important, as they provide vital services such as pest control and seed dispersal (Sekercioglu et al. 2004; Whelan et al. 2008; Wenny et al. 2011). From an ecosystem perspective, losses of the most common and abundant species might result in the deterioration of ecosystem functions and services and affect other species through changes in multitrophic interactions, such as predator-prey relationships (Gaston 2010). The more recent increase in common and abundant species, driven mostly by resident forest and settlement birds, is, therefore, encouraging.

\section{Climate change: losers and winners}

A clear pattern emerged for trends grouped by climatic niche of the species. Warm-adapted common bird species showed on average positive trends in the 1990s and 2000s, and after a period of stagnation, a new increase was detected for recent years. Cold-adapted common bird species decreased until the late 2000s, but declines leveled off afterwards. This period of stagnation from 2009 to 2013 might result from relatively cold winters from 2009 to 2011 compared to the long-term-mean (Deutscher Wetterdienst, Climate Data center, https://www.dwd.de/EN/climate_environment/cdc/ cdc.html). Climate-change-related drivers of bird population trends are well established (Crick 2004) and include changes in migration systems, the timing of breeding and reproductive success, host-parasite and predator-prey interactions (Dunn and Møller 2019). Range shifts can also lead to perceived declines in a region, while increases are detected in another, as shown for waterbirds (Lehikoinen et al. 2013). Climate change is predicted to outpace the adaptive capacity of birds especially in nordic and alpine environments, and habitat loss there will lead to range contractions and extinction (Dunn and Møller 2019).

\section{Robustness of the multi-species indicators and representativeness of the species set}

The leave-one-out sensitivity analysis showed that the chosen land-cover and trait categories are often robust against extreme trends in single species, especially where the number of included species was high. The omission of single species could lead to changes in magnitude in groups with low sample size (e.g., in wetland birds, farmland insectivores or species wintering in the Sahel). Strong changes in trend direction (a switch from overall decline to overall increase) were only observed for omnivorous birds. However, the general patterns of the MSI across land-cover categories correspond well with the aggregated trends of the German national bird trend indicator (Dröschmeister and Sukopp 2009). This indicator is routinely used to assess progress towards certain policy aims by setting species trends against a targeted population size index in the year 2030. The indicator does not contain all 
available species with data, but focuses on a set selected by experts and believed to contain species that allow to track major environmental changes. The general overlap between this expert assessment and our data-driven approach suggests that both approaches are useful to reach this aim, confirming a generally low sensitivity of multispecies indicators to species selection methods (Renwick et al. 2012).

The set of species considered here comprises 93 commoner species with a population size $>10,000$ pairs, for which continuous data series for the period 1990-2018 are available, and is based on a large sample of plots selected in a rigorous sampling design (at least since 2005). The "representativeness" of the selected set of species for all 261 regular German breeding bird species varied across traits (Fig. S7). Considerable underrepresentation is obvious for waterbirds, ground-breeders and carnivorous species, and overrepresentation for forest birds, tree-breeders and forest insectivores (Fig. S7). Trend data for some species not covered here are available, but not based on sampling schemes with comparable statistical rigorousness. A first screening of (often expert-based) potential trend magnitudes in all German breeding species does suggest that the patterns detected here with Common Bird Monitoring data were unlikely to deviate much, if all German breeding bird species had been assessed (Gerlach et al. 2019). We do acknowledge though that the limited representativeness of the data used here for certain traits calls for further, species-specific analyses on the drivers of trends especially in birds of prey and the rarest species.

\section{Change points}

In several trait groups, the directional change of the MSI in 2010 was significant. This concerned forest birds and tree-nesters, bird nesting on buildings, granivorous and invertebrate-feeding birds, both long- and short-distance migrants (but not residents), species with broad habitat preferences and abundant and common birds (but not less common ones). It is difficult to identify common underlaying patterns and drivers of these changepoints (e.g., a change in forest management or disturbance, changes in agricultural management) on the aggregation level we use here and species-specific studies might be needed. It seems unlikely that the significance of the changepoint is a methodological artefact, perhaps arising from the transition between the two monitoring programs and the associated trend combination. In this case, the changepoint should feature in all groups, and should probably be earlier, around 2005 when the new scheme got off the ground.
Future scrutinization of the time series in both programs seems a rewarding endeavor.

\section{A roadmap for research}

Follow-up research seems especially promising where plausible drivers of the trends presented here are unclear. We suggest ten priority research areas:

1. Collate and relate spatial data on changes in management unit size (field size), pesticide and fertilizer application, crop rotation, grassland conversion rates and management intensity to changes in bird trends, accompanied by experimental field studies that allow to reveal causal relationships.

2. Investigate the role of both historically increasing wood volume and current increases in forest disturbance on forest birds.

3. Relate changes in water quality (including nutrient loads) since the early 1990 s to changes in breeding waterbird abundance and community composition.

4. Examine the interactions between recently discovered, precipitous insect declines and population trends in insectivorous birds.

5. Extend efforts to predict bird community responses to climate change by integrating traits, species interactions and physiological niches.

6. Extend efforts to synthesize data on bird migration routes (from ringing recoveries and tracking studies) and link trends of residents, short-distance and longdistance migrants to climate change and land-use change throughout the annual cycle.

7. Mobilize unstructured citizen science data (e.g., from www.ornitho.de) for trend estimation and advance methods to account for bias in these data.

8. Mobilize historical data (e.g., from birdwatchers notebooks, historical surveys) to set more quantitative baselines in bird abundance and distribution.

9. Develop systematic, robust monitoring programmes for rare, wetland and alpine species to increase the number of species available for national assessments.

10. Evaluate the efficacy of protected areas to preserve birds of conservation concern and assess how protected area management affects bird populations and trends.

Acknowledgements We thank the thousands of volunteers that annually surveyed the large number of monitoring plots. Johannes Wahl gave advice on the interpretation of the species traits. We thank three reviewers for helpful comments on a previous version of the paper. The German bird monitoring is funded through an agreement between the German government and the federal states ("Verwaltungsvereinbarung Vogelmonitoring"). 
Funding Open Access funding enabled and organized by Projekt DEAL.

Open Access This article is licensed under a Creative Commons Attribution 4.0 International License, which permits use, sharing, adaptation, distribution and reproduction in any medium or format, as long as you give appropriate credit to the original author(s) and the source, provide a link to the Creative Commons licence, and indicate if changes were made. The images or other third party material in this article are included in the article's Creative Commons licence, unless indicated otherwise in a credit line to the material. If material is not included in the article's Creative Commons licence and your intended use is not permitted by statutory regulation or exceeds the permitted use, you will need to obtain permission directly from the copyright holder. To view a copy of this licence, visit http://creativecommons.org/licenses/by/4.0/.

\section{References}

Bairlein F, Dierschke J, Dierschke V et al (2014) Atlas des Vogelzugs-Ringfunde deutscher Brut-und Gastvögel, 1st edn. AulaVerlag, Wiebelsheim

Batáry P, Gallé R, Riesch F et al (2017) The former iron curtain still drives biodiversity-profit trade-offs in German agriculture. Nat Ecol Evol 1:1279-1284. https://doi.org/10.1038/s4155 9-017-0272-x

Beresford AE, Sanderson FJ, Donald PF et al (2019) Phenology and climate change in Africa and the decline of Afro-Palearctic migratory bird populations. Remote Sens Ecol Conserv 5:55-69. https ://doi.org/10.1002/rse2.89

Berthold P (2008) Vogelzug—eine aktuelle Gesamtübersicht, 6th edn. Wissenschaftliche Buchgesellschaft, Darmstadt

Bowler DE, Heldbjerg H, Fox AD et al (2019) Long-term declines of European insectivorous bird populations and potential causes. Conserv Biol 33:1120-1130. https://doi.org/10.1111/cobi.13307

Busch M, Katzenberger J, Trautmann S et al (2020) Drivers of population change in common farmland birds in Germany. Bird Conserv Int. https://doi.org/10.1017/S0959270919000480

Bystrak D (1981) The North American breeding bird survey. Stud Avian Biol 6:34-41

Cresswell W, Kazeh NW, Patchett R (2019) Local human population increase in the non-breeding areas of long-distance migrant bird species is only weakly associated with their declines, even for synanthropic species. Divers Distrib. https://doi.org/10.1111/ ddi. 13006

Crick HQP (2004) The impact of climate change on birds. Ibis 146:4856. https://doi.org/10.1111/j.1474-919X.2004.00327.x

Deutsche Ornithologen-Gesellschaft (DO-G), Fachgruppe Agrarvögel (2019) Weiterentwicklung der Gemeinsamen Agrarpolitik ab 2021: Erfordernisse zum Erhalt unserer Agrarvögel. Vogelwarte 345-357

Devictor V, Julliard R, Couvet D, Jiguet F (2008) Birds are tracking climate warming, but not fast enough. Proc R Soc B Biol Sci 275:2743-2748. https://doi.org/10.1098/rspb.2008.0878

Donald PF, Green RE, Heath MF (2001) Agricultural intensification and the collapse of Europe's farmland bird populations. Proc R Soc Lond B 268:25-29. https://doi.org/10.1098/rspb.2000.1325

Donald PF, Sanderson FJ, Burfield IJ et al (2007) International conservation policy delivers benefits for birds in Europe. Science 317:810-813. https://doi.org/10.1126/science.1146002

Dornbusch M, Grün G, König H, Stephan B (1968) Zur Methode der Ermittlung von Brutvogel-Siedlungsdichten auf Kontrollflächen. Mitteilungen der Interessengemeinschaft Avifaunistik der DDR $1: 7-16$
Dröschmeister R, Sukopp U (2009) Indicators and conservation policy: the German sustainability indicator for species diversity as an example. Avocetta 33:149-156

Dunn PO, Møller AP (eds) (2019) Effects of climate change on birds, 2nd edn. Oxford University Press, Oxford

Eng ML, Stutchbury BJM, Morrissey CA (2017) Imidacloprid and chlorpyrifos insecticides impair migratory ability in a seed-eating songbird. Sci Rep 7:1-9. https://doi.org/10.1038/s41598-01715446-x

European Environment Agency (2019) Report on progress and implementation (Article 12, Birds Directive). EIONET Central Data Repository. https://cdr.eionet.europa.eu/de/eu/art12/envxztrqw/. Accessed 25 May 2020

Federal Ministry of Food and Agriculture (2015) The forests in Germany. Selected results of the third national forest inventory. https ://www.bmel.de/SharedDocs/Downloads/DE/Broschueren/bunde swaldinventur3.html

Flade M, Schwarz J (2004) Ergebnisse des DDA-Monitoringprogramms, Teil II: Bestandsentwicklung von Waldvögeln in Deutschland 1989-2003. Vogelwelt 125:177-213

Freeman SN, Noble DG, Newson SE, Baillie SR (2007) Modelling population changes using data from different surveys: the Common Birds Census and the Breeding Bird Survey. Bird Study 54:61-72. https://doi.org/10.1080/00063650709461457

Gaston KJ (2010) Valuing common species. Science 327:154-155. https://doi.org/10.1126/science.1182818

Gedeon K, Grüneberg C, Mitschke A et al (2014) Atlas Deutscher Brutvogelarten. Atlas of German breeding birds, Stiftung Vogelmonitoring Deutschland und Dachverband Deutscher Avifaunisten, Münster

George K (2004) Veränderungen der ostdeutschen Agrarlandschaft und ihrer Vogelwelt insbesondere nach der Wiedervereinigung Deutschlands. Druck-Zuck GmbH, Halle (Saale)

Gerlach B, Dröschmeister R, Langgemach T et al (2019) Vögel in Deutschland-Übersichten zur Bestandssituation. DDA, BfN, LAG VSW, Münster

Görn S, Schulze F, Fischer K (2015) Effects of fen management on bird communities in north-eastern Germany. J Ornithol 156:287-296. https://doi.org/10.1007/s10336-014-1125-x

Gregory RD, Skorpilova J, Vorisek P, Butler S (2019) An analysis of trends, uncertainty and species selection shows contrasting trends of widespread forest and farmland birds in Europe. Ecol Ind 103:676-687. https://doi.org/10.1016/j.ecolind.2019.04.064

Grendelmeier A, Flade M, Pasinelli G (2019) Trophic consequences of mast seeding for avian and mammalian seed and non-seed consumers in European temperate forests. J Ornithol 160:641-653. https://doi.org/10.1007/s10336-019-01644-z

Hallmann CA, Sorg M, Jongejans E et al (2017) More than 75 percent decline over 27 years in total flying insect biomass in protected areas. PLoS ONE 12:e0185809. https://doi.org/10.1371/journ al.pone. 0185809

Heldbjerg H, Sunde P, Fox AD (2018) Continuous population declines for specialist farmland birds 1987-2014 in Denmark indicates no halt in biodiversity loss in agricultural habitats. Bird Conserv Int 28:278-292. https://doi.org/10.1017/S0959270916000654

Inger R, Gregory R, Duffy JP et al (2015) Common European birds are declining rapidly while less abundant species' numbers are rising. Ecol Lett 18:28-36. https://doi.org/10.1111/ele.12387

Jerrentrup JS, Dauber J, Strohbach MW et al (2017) Impact of recent changes in agricultural land use on farmland bird trends. Agr Ecosyst Environ 239:334-341. https://doi.org/10.1016/j. agee.2017.01.041

Kamp J, Trappe J, Dübbers L, Funke S (2020) Impacts of windstorminduced forest loss and variable reforestation on bird communities. For Ecol Manage 478:118504. https://doi.org/10.1016/j.forec o.2020.118504 
Lehikoinen A, Jaatinen K, Vähätalo AV et al (2013) Rapid climate driven shifts in wintering distributions of three common waterbird species. Glob Change Biol 19:2071-2081

Lennon RJ, Peach WJ, Dunn JC et al (2020) From seeds to plasma: Confirmed exposure of multiple farmland bird species to clothianidin during sowing of winter cereals. Sci Total Environ 723:138056. https://doi.org/10.1016/j.scitotenv.2020.138056

Mikusiński G, Gromadzki M, Chylarecki P (2001) Woodpeckers as indicators of forest bird diversity. Conserv Biol 15:208-217. https ://doi.org/10.1111/j.1523-1739.2001.99236.x

Mitschke A, Sudfeldt C, Heidrich-Riske H, Dröschmeister R (2005) Das neue Brutvogelmonitoring in der Normallandschaft Deutschlands-Untersuchungsgebiete, Erfassungsmethode und erste Ergebnisse. Vogelwelt 126:127-140

Newton I (2004) The recent declines of farmland bird populations in Britain: an appraisal of causal factors and conservation actions. Ibis 146:579-600. https://doi.org/10.1111/j.1474919X.2004.00375.x

Nicolai B (1993) Atlas der Brutvögel Ostdeutschlands. Gustav Fischer Verlag, Jena

Oelke H (1968) Empfehlungen für Untersuchungen der Siedlungsdichte von Sommervogelbeständen. Vogelwelt 89:69-78

Pannekoek J, Van Strien A (2001) TRIM 3 manual trends \& indices for monitoring data. CBS Statistics Netherlands, Voorburg, The Netherlands

Pellissier V, Schmucki R, Pe'er G et al (2019) Effects of natura 2000 on nontarget bird and butterfly species based on citizen science data. Conserv Biol 34:666-676. https://doi.org/10.1111/cobi.13434

Reif J, Voříšek P, Šastný K et al (2008) Agricultural intensification and farmland birds: new insights from a central European country: Agricultural intensification and farmland birds. Ibis 150:596-605. https://doi.org/10.1111/j.1474-919X.2008.00829.x

Renwick AR, Johnston A, Joys A et al (2012) Composite bird indicators robust to variation in species selection and habitat specificity. Ecol Ind 18:200-207. https://doi.org/10.1016/j.ecolind.2011.11.008

Robb GN, McDonald RA, Chamberlain DE, Bearhop S (2008) Food for thought: supplementary feeding as a driver of ecological change in avian populations. Front Ecol Environ 6:476-484. https://doi. org/10.1890/060152

Rosenberg KV, Dokter AM, Blancher PJ et al (2019) Decline of the North American avifauna. Science 366:120-124. https://doi. org/10.1126/science.aaw1313

Rosin ZM, Hiron M, Żmihorski M et al (2020) Reduced biodiversity in modernized villages: a conflict between sustainable development goals. J Appl Ecol 1365-2664:13566. https://doi. org/10.1111/1365-2664.13566

Šálek M, Bažant M, Żmihorski M (2018) Active farmsteads are yearround strongholds for farmland birds. J Appl Ecol 55:1908-1918. https://doi.org/10.1111/1365-2664.13093

Sanderson FJ, Donald PF, Pain DJ et al (2006) Long-term population declines in Afro-Palearctic migrant birds. Biol Cons 131:93-105. https://doi.org/10.1016/j.biocon.2006.02.008

Sanderson FJ, Kucharz M, Jobda M, Donald PF (2013) Impacts of agricultural intensification and abandonment on farmland birds in Poland following EU accession. Agric Ecosyst Environ 168:1624. https://doi.org/10.1016/j.agee.2013.01.015

Schekkerman H (2008) Precocial problems-shorebird chick performance in relation to weather, farming, and predation. Dissertation, Rijksuniversiteit. Groningen. https://www.rug.nl/research/portal/ files/47930399/SciContrib24.pdf

Schelhaas M-J, Nabuurs G-J, Schuck A (2003) Natural disturbances in the European forests in the 19th and 20th centuries. Glob Change Biol 9:1620-1633. https://doi.org/10.104 6/j.1365-2486.2003.00684.x
Schmeller D, Henle K, Loyau A et al (2012) Bird-monitoring in Europe a first overview of practices, motivations and aims. Nat Conserv 2:41-57. https://doi.org/10.3897/natureconservation.2.3644

Schwarz J, Flade M (2000) Ergebnisse des DDA-Monitoringprogramms. Teil I: Bestandsänderungen von Vogelarten der Siedlungen seit 1989. Vogelwelt 121:87-106

Seibold S, Gossner MM, Simons NK et al (2019) Arthropod decline in grasslands and forests is associated with landscape-level drivers. Nature 574:671-674. https://doi.org/10.1038/s41586-019-1684-3

Sekercioglu CH, Daily GC, Ehrlich PR (2004) Ecosystem consequences of bird declines. Proc Natl Acad Sci 101:18042-18047. https://doi.org/10.1073/pnas.0408049101

Senf C, Pflugmacher D, Zhiqiang Y et al (2018) Canopy mortality has doubled in Europe's temperate forests over the last three decades. Nat Commun 9:4978. https://doi.org/10.1038/s41467-018-07539 $-6$

Senf C, Sebald J, Seidl R (2020) Increases in canopy mortality and their impact on the demographic structure of Europe's forests. bioRxiv. https://doi.org/10.1101/2020.03.30.015818 (preprint)

Senf C, Seidl R (2020) Mapping the forest disturbance regimes of Europe. Nat Sustain.https://doi.org/10.1038/s41893-020-00609-y

Soldaat LL, Pannekoek J, Verweij RJT et al (2017) A Monte Carlo method to account for sampling error in multi-species indicators. Ecol Ind 81:340-347. https://doi.org/10.1016/j.ecoli nd.2017.05.033

Stephens PA, Mason LR, Green RE et al (2016) Consistent response of bird populations to climate change on two continents. Science 352:84-87. https://doi.org/10.1126/science.aac4858

Storchová L, Hořák D (2018) Life-history characteristics of European birds. Global Ecol Biogeogr 27:400-406. https://doi.org/10.1111/ geb. 12709

Swinnen JFM, Buckwell AE, Mathijs E (2018) Agricultural privatisation, land reform and farm restructuring in Central and Eastern Europe. Routledge, London

Swinnen JFM, Vranken L (2010) Reforms and agricultural productivity in Central and Eastern Europe and the Former Soviet Republics: 1989-2005. J Prod Anal 33:241-258. https://doi.org/10.1007/ s11123-009-0162-6

Traba J, Morales MB (2019) The decline of farmland birds in Spain is strongly associated to the loss of fallowland. Sci Rep 9:9473. https ://doi.org/10.1038/s41598-019-45854-0

Vickery JA, Adams WM (2020) Action before certainty for Africa's European migrant birds. Oryx 54:1-2. https://doi.org/10.1017/ S0030605319001273

Vickery JA, Ewing SR, Smith KW et al (2014) The decline of AfroPalaearctic migrants and an assessment of potential causes. Ibis 156:1-22. https://doi.org/10.1111/ibi.12118

Wenny DG, DeVault TL, Johnson MD et al (2011) The need to quantify ecosystem services provided by birds. Auk 128:1-14. https://doi. org/10.1525/auk.2011.10248

Whelan CJ, Wenny DG, Marquis RJ (2008) Ecosystem services provided by birds. Ann N Y Acad Sci 1134:25-60. https://doi. org/10.1196/annals.1439.003

Yoccoz NG, Nichols JD, Boulinier T (2001) Monitoring of biological diversity in space and time. Trends Ecol Evol 16:446-453. https ://doi.org/10.1016/S0169-5347(01)02205-4

Zakkak S, Radovic A, Nikolov SC et al (2015) Assessing the effect of agricultural land abandonment on bird communities in southern-eastern Europe. J Environ Manag 164:171-179. https://doi. org/10.1016/j.jenvman.2015.09.005

Publisher's Note Springer Nature remains neutral with regard to jurisdictional claims in published maps and institutional affiliations. 